University at Albany, State University of New York

Scholars Archive

2018

\title{
Is Informal Financial Aid Good for Health? Evidence from Kyrgyzstan, a Low-Income Post-Socialist Nation in Eurasia
}

Jildyz Urbaeva

University at Albany, State University of New York, zurbaeva@albany.edu

Theodore Jackson

University at Albany, State University of New York, tfjackson@albany.edu

Daejun Park

University at Albany, State University of New York, dpark7@albany.edu

Follow this and additional works at: https://scholarsarchive.library.albany.edu/ssw_sw_scholar

Part of the Social Work Commons

\section{Recommended Citation}

Urbaeva, Jildyz; Jackson, Theodore; and Park, Daejun, "Is Informal Financial Aid Good for Health?

Evidence from Kyrgyzstan, a Low-Income Post-Socialist Nation in Eurasia" (2018). Social Welfare Faculty Scholarship. 10.

https://scholarsarchive.library.albany.edu/ssw_sw_scholar/10

This Article is brought to you for free and open access by the Social Welfare at Scholars Archive. It has been accepted for inclusion in Social Welfare Faculty Scholarship by an authorized administrator of Scholars Archive. For more information, please contact scholarsarchive@albany.edu. 


\section{Is Informal Financial Aid Good for Health? Evidence from Kyrgyzstan, a Low-Income Post-Socialist Nation in Eurasia}

Jildyz Urbaeva, Theodore Jackson, and Daejun Park

The importance of social capital and economic advantage for health is well established in literature. The relationship between health and social capital through informal financial aid is less understood. Using representative data $(N=7,474)$, authors explored an association between informal financial aid and health satisfaction in Kyrgyzstan, a post-socialist low-income country in Eurasia. Multilevel modeling revealed significant associations between informal aid and health. Cross-level interactions between individual and neighborhood financial aid were also significantly associated with health satisfaction. The results suggest that (a) social capital is influenced by socioeconomic status of the person, and (b) paths between informal aid and health vary among individuals at different levels of socioeconomic structure. Authors conclude the article with a discussion of the implications for social work practice and policy to improve health outcomes for disadvantaged individuals.

Key words: cross-level interactions; individual and neighborhood social capital; informal financial aid; post-socialist Eurasian nations; social capital and health 
The current discourse about the role played by social capital in population health relies on a substantive body of theoretical and empirical evidence. Theorists argue that social relations and accompanying norms of trust and reciprocity can have powerful effects on health (Putnam, 2004). For example, Putnam, Leonardi, and Nanetti (1993), using decades of data from Italy, demonstrated that regions with strong social networks had made the most economic and other progress. The empirical literature further suggests a modest but persistent influence of social capital on health in developed countries (Gilbert, Quinn, Goodman, Butler, \& Wallace, 2013; Kim, Subramanian, \& Kawachi, 2006; Mohnen, Groenewegen, Völker, \& Flap, 2011; Poortinga, 2006). Similar results have been identified in developing countries (Afifi, Nakkash, \& Khawaja, 2010; Hurtado, Kawachi, \& Sudarsky, 2011). The limited evidence available from post-Soviet countries suggests that social capital is also a strong determinant of health in these regions (d'Hombres, Rocco, Suhrcke, \& McKee, 2010; Goryakin, Suhrcke, Rocco, Roberts, \& McKee, 2014).

Despite the relevance of social capital theory for social work research and interventions, limited evidence has been developed so far on potential applications for improving human development outcomes at individual and community levels (Healy \& Hampshire, 2002; Midgley \& Livermore, 1998). The post-Soviet nations of Eurasia represent a fascinating case for studying the influence of social capital on well-being and health. The beginning of the transition to a market economy weakened the welfare state's capacity to provide social assistance, which resulted in households relying heavily on their own social networks for mobility and economic support. There is evidence regarding the positive effects of micro-financing programs on healthrelated outcomes in developing economies (Abekah-Nkrumah, Asewer Abor, Abor, \& Adjasi, 2011; Madhani, Tompkins, Jack, \& Fisher, 2015), yet we know little about the role of social 
networks in coping with economic stress in these countries. In this article, Kyrgyzstan, a lowincome country with robust social networks that influence community mobilization and political participation (Radnitz, 2005), will be used as an example of how the dynamics of health and informal aid from social networks are intertwined.

\section{Intersectionality between Social and Economic Relations}

Social relations, particularly those relating to financial aid, often imply reciprocity. Putnam et al. (1993) defined reciprocity as "a continuing relationship of exchange that is at any given time unrequited or imbalanced, but that involves mutual expectations that a benefit granted now should be repaid in the future" (p. 172). Reciprocity in social relations has many positive effects, such as providing economic and employment opportunities and contributing to peace building in conflict zones (Narayan-Parker, 1999). At the same time, reciprocity can result in the exclusion of disadvantaged groups and expectations that successful members of social networks share their resources, which may result in the depletion of resources and demotivate successful members from participation in these networks (Narayan-Parker, 1999).

Social relations are often negotiated by both individuals and families through participation in life-cycle events, such as funerals and weddings, where gift exchanges are extremely important. Research from Kyrgyzstan shows that participation in such events adds financial pressure on families, as they have to make considerable sacrifices to afford gift-giving (Provis, 2015). The inability to contribute monetarily to life-cycle events can negatively influence a family's status within the community (Kuehnast \& Dudwick, 2002). If a family cannot afford to make a timely contribution, they will not attend the event and will give a gift later instead (G. Botoeva, 2015). 
To maintain good relations within social networks, some families take high-interest loans from banks and micro-crediting organizations to contribute to and organize life-cycle events (G. Botoeva, 2015). In post-industrial societies, families can obtain short- and long-term loans from financial institutions; however, this is not as common in developing economies, where families often do not have immediate, formal access to capital (Van Bastelaer, 2002). Rather, families receive informal loans from friends, coworkers, and kin within their social network, with an expectation that this aid will, in some way, be reciprocated (Van Bastelaer, 2002). Commercial loans are available to higher-income families who have resources to guarantee repayment to financial institutions. In contrast, lower-income families are less likely to have access to loans, since lenders may doubt their ability to pay them back (Van Bastelaer, 2002).

Putnam et al. (1993) noted that social networks impose sanctions against those who are unable to participate in reciprocal relations. As discussed earlier, the inability to contribute to gift giving excludes the poor from significant life-cycle events and their associated social networks (Narayan-Parker, 1999; Provis, 2015), creating different social trajectories for lower- and higherincome people. Whereas lower-income people have to rely on social networks for assistance, higher-income individuals and families use their networks to advance their social status (Kuehnast \& Dudwick, 2002). Furthermore, the exclusion of poor people from higher-status networks leads to social stratification based on income (Narayan-Parker, 1999; G. Botoeva, 2015). Because of this dynamic, the social networks of poor people are often smaller than those of higher-income people, resulting in low levels of social capital among poor families (Kuehnast \& Dudwick, 2002).

\section{Informal Financial Aid}


In countries transitioning from socialism to a market economy, such as Kyrgyzstan, the comparative value of welfare assistance is reduced, and families in need more often turn to informal social networks for assistance (Narayan-Parker, 1999). Researchers note that people in Kyrgyzstan define their personal happiness and well-being in relation to their relationships with family, friends, and children (Borbieva, 2012; A. Botoeva \& Spector, 2013). However, as social and economic inequalities increase, social relations become more transactional, influencing the quality of and individual satisfaction with relationships (Borbieva, 2012). Lower- and higherincome people differ in their patterns of monetary exchanges. Lower-income people borrow money to survive, and failure to return personal loans in time negatively affects their relationships with kin and friends (Kuehnast \& Dudwick, 2002). Higher-income families, on the other hand, may not need financial assistance from their social networks, but choose to use monetary exchanges as an efficient mechanism for settling reciprocal expectations, an option that is often unavailable for the poor (Oka, 2015).

Even when poor families receive assistance through social networks, they cannot rely on it for long in Kyrgyzstan. Howell (1996) described coping mechanisms used by Kyrgyzstani families struggling financially. In the first stage of financial deprivation, families get by without depleting their assets and productive resource base; in the second stage of the financial hardship, families try to maintain their resource base by limiting food expenses and purchases of luxury items. Initially, families rely on their social networks to cope with these hardships, but as the deprivation deepens, the reciprocal network shrinks, leaving families more vulnerable to the effects of financial difficulties (Howell, 1996). 
This article examines a financial dimension of social relations (informal financial aid) to understand the relationship between social networks and perceived health in Kyrgyzstan. The importance of monetary exchanges for various purposes within social networks, as demonstrated by previous research, makes informal financial relations an important factor in the overall wellbeing of families. Furthermore, research shows that income inequality is related to lower social capital and leads to higher rates of mortality (Kawachi, Kennedy, Lochner, \& Prothrow-Stith, 1997). Our hypotheses are that (a) individual social capital is positively related to health satisfaction, and (b) the robustness of neighborhood social capital is positively related to health satisfaction. We define individual social capital as access to cash loans and robustness of neighborhood social capital as proportional to the number of people involved in giving and receiving financial aid.

Our operationalization of health status is based on reported health satisfaction. We assessed concurrent validity of the health satisfaction variable using correlations with the healthrelated variables high blood pressure $(r=-0.22, p<.01)$, any recent diseases $(r=-0.15, p<.05)$, no recent diseases $(r=0.22, p<.01)$, and chronic illness $(r=-0.37, p<.01)$, with results showing that this measure was valid. Previous literature has also demonstrated that self-reported measures of health correlate with mortality and other health outcomes (Singh-Manoux et al., 2006).

The current study contributes to the literature on social determinants of health in three ways. First, it increases our understanding of how social capital in the form of informal financial aid, or lack thereof, influences health satisfaction. Despite the fact that informal financial aid is an important coping strategy of households in developing economies, the relationship between informal financial aid and health satisfaction has received little attention. Second, the study adds 
to the limited body of evidence on social capital and health in social work research and interventions. An understanding of this dynamic can help in improving policy development and social work interventions in developing countries. Third, this study focuses on a low-income country, since the relationship between social capital and health determinants in low-income countries has not yet received sufficient attention from researchers (Agampodi, Agampodi, Glozier, \& Siribaddana, 2015).

\section{Method}

The data used in this study are from the Life in Kyrgyzstan (LIK) survey conducted in 2012. The LIK survey was conducted by a data collection firm in Kyrgyzstan, in collaboration with research universities and organizations in Kyrgyzstan and Germany (Brück et al., 2014). The survey aimed to provide representative individual and household data, with 8,066 individual respondents. The LIK used stratified two-stage random sampling. The rural and urban areas in each region and two major cities formed 16 strata, from which rural communities or city neighborhood were sampled with probability proportionate to size. During the second stage, 25 households were randomly selected in each community or neighborhood. A sampling frame for households was based on the 2009 population census data.

Approximately 120 trained personnel collected data, and 40 supervisors and eight regional supervisors were involved in the verification of data quality. Prior to collecting data, pilot surveys were conducted in a rural community and an urban neighborhood. The response rates varied between 95 percent and 99 percent across questionnaire modules. For the current study, we merged several modules examining the individual and household levels: subjective well-being, education, health, and social life. Because of data inconsistencies and the elimination 
of missing data relevant to the study variables, the analytic sample for the current study included 7,474 individuals.

\section{Measures}

Dependent Variable. We used a variable representing health satisfaction. The 11-point scale ranged from $0=$ extremely unsatisfied to $10=$ extremely satisfied.

Independent Variables. An individual-level variable, access to a small cash loan, was formed from the survey question, "If you suddenly needed $\sim \$ 50$, how many people you know would lend you money?" with responses coded dichotomously $(1=$ some/many, $0=$ hard to say/very few/nobody). Another individual-level social capital variable, access to a house repair loan, was constructed from the question, "If your house was damaged and you needed help to repair it quickly, whom would you ask for help?" with responses coded as $1=$ relatives/neighbors/friends/work contacts/others and $0=$ nobody.

To measure neighborhood-level social capital, we created variables representing proportions of people involved in giving and receiving informal financial aid within the neighborhood. We used the survey question, “To how many people did you give any financial aid in the last 12 months?" to derive a variable, percentage of people who gave financial aid. We used the survey question, "From how many people did you receive any financial aid in the last 12 months?" to derive the variable percentage of people who received financial aid. These variables were created using the following equation: number of those who gave/received financial aid $=$ mean score per neighborhood $\times 100$.

Control Variables. Given that multiple factors influence health status, potentially affecting the relationship between the dependent and independent variables, we included a number of health-related variables in the multivariate model. We controlled for the presence of 
chronic disease, body mass index (BMI), age, gender, relationship status, and ethnicity to adjust our models for their confounding influences. For missing values for the income variable, we used a self-reported measure of household income satisfaction as a proxy variable. Based on statistical differences between categories, we created three dichotomous variables: low level of income satisfaction (0-4), middle level of income satisfaction (5-6), and high level of income satisfaction (7-10).

\section{Analysis}

A chi-square test was used to assess the differences between individuals who had access to informal loans and those who did not. The mean differences between these two groups were assessed using a two-sample correlated $t$ test. To assess the relationship between health satisfaction and social capital, we fitted multilevel linear regression models with settings (urban and rural) as a second-level variable. Models were fitted in three sequential steps as follows: (1) individual-level social capital, (2) neighborhood-level social capital, and (3) cross-level interactions between individual and neighborhood social capital. We included all control variables at each step of the analysis, which was completed using Stata 14 (StataCorp, 2015).

\section{Results}

The final sample (see Table 1) included 7,474 respondents. Of these, 33.01 percent were an ethnic minority, 69.17 percent were married, and 53.22 percent were female. The mean age was 40.57 years, and 65.23 percent of respondents lived in rural areas. Those reporting a low level of income satisfaction were at 14.56 percent, whereas 35.85 percent reported a middle level of income satisfaction and 49.60 percent reported a high level of income satisfaction. Of final sample respondents, 35.45 percent had access to informal cash loans and 83.71 percent had access to informal loans for house repairs. The mean percentage of people who gave financial aid 
within their neighborhood was 20.70 percent, and the mean percentage of people who received financial aid was 20 percent.

Table 2 shows characteristics of people who had access to loans versus people who did not. Demographically, people with access to small cash loans and house repair loans reported higher health satisfaction. Individuals reporting access to both types of informal loans were more likely to be married and have higher income, and they tended to live in neighborhoods where more people gave and received informal financial aid. People who had access to cash loans were likely to be older, male, and had higher BMI than their counterparts who did not report having access to cash loans.

Table 3 displays the results of multilevel linear regression models predicting health satisfaction. Diagnostics tests showed a small variance inflation factor (VIF) for a regression model (mean VIF $=7.67$ ). Having access to informal cash loans and house repair loans was positively associated with health. After we added neighborhood-level social capital measures (model 2), individual social capital maintained its positive association with health. Communitylevel social capital had varying influences on health. An increase in the proportion of people in the neighborhood who gave financial aid was associated with improved health, while an increase of the proportion of people who received financial aid was associated with reduced health.

Cross-level interactions between individual and neighborhood informal aid demonstrated strong results (model 3). People with access to informal loans were less satisfied with their health if more financial aid was given in their neighborhood, and individuals without access were more satisfied in those generous neighborhoods. Individuals with access to cash loans were more satisfied with health if they lived in a neighborhood with a higher proportion of received aid, 
whereas individuals with no access to informal loans were less satisfied with their health in neighborhoods receiving more aid (see Figure 1).

\section{Discussion}

Population health declined in post-Soviet countries after the transition to market economies. In the absence of strong redistributive policies, the disparities in social and economic opportunities have widened, leaving large groups unable to cope with these transitional effects. Because of a lack of social protection mechanisms, the most disadvantaged groups are left to rely on informal assistance from their social networks. Previous research has established that access to microfinance programs is related to better health outcomes (Abekah-Nkrumah et al., 2011), but we know little about the influence of informal financial aid in developing economies. The current study is among the first to assess the relationship between informal financial aid and health.

The findings should be interpreted cautiously because of at least two limitations. The first is that common method variance among study variables may occur because all variables were reported by respondents (P. Podsakoff, MacKenzie, Lee, \& N. Podsakoff, 2003). The second limitation is that the cross-sectional study data precludes conclusions about the effects of financial aid on long-term health satisfaction. Future studies would benefit from using longitudinal data.

Our first hypothesis, that access to financial aid is good for health, was supported by the findings. Our second hypothesis, that robust neighborhood social capital in the form of informal financial aid is good for health, was partially supported by the findings. Previous studies found that access to informal loans was associated with higher socioeconomic status (G. Botoeva, 2015; Cox, Eser, \& Jimenez, 1997), and our bivariate analysis shows the same trend (see Table 
2). Our results indicate that access to cash loans could be indicative of the overall socioeconomic status of an individual or of a neighborhood. For example, living in a neighborhood where more people give aid was good for health, because it could reflect the higher socioeconomic status of the neighborhood. Similarly, living in a neighborhood with more people receiving aid was negative for health, which could indicate a lower socioeconomic status of the neighborhood as a whole. In Kyrgyzstan, social capital is strongly connected to one's ability to reciprocate through monetary and other favors, and having social capital also means a higher socioeconomic status.

This trend becomes even more evident when we assess the relationship between health and access to financial aid in the neighborhood context. When people with more social capital lived in neighborhoods with lower social capital, health satisfaction was reduced. This could mean that individuals of high socioeconomic status are expected to provide more aid in their neighborhoods, which could negatively affect their health perception due to stress and resource depletion. Living in high social capital neighborhoods was good for the health of people with access to social capital because it may have increased their socioeconomic advantage by having both individual and neighborhood resources. Individuals with lower social capital living in neighborhoods with less social capital were more satisfied with their health, probably because they lived among people of a similar socio-economic background and did not feel isolated due to the inability to reciprocate social interactions. However, when people with less social capital lived in neighborhoods with robust social capital, their health satisfaction was reduced because they were unable to benefit from the neighborhood social capital. We speculate that people with lower social capital and socioeconomic status were excluded from capital exchanges in these neighborhoods because of their inability to reciprocate. 
The results of this study suggest a potential accumulation of social and economic disadvantages among the poor. The study also contributes to the literature on health disparities, especially in the area of stratification through social relations and economic status, and community economic development. We are used to thinking that poor individuals and communities can always benefit from social capital (Narayan-Parker, 1999). However, in the context of Kyrgyzstan, this may not be the case. Social capital converges with the overall socioeconomic status of people within their neighborhoods. Poor people are more likely to have poorer health outcomes in richer neighborhoods because of their exclusion from social relations. As for better-off individuals, their health is negatively affected in poor neighborhoods, and eventually they may choose to live in neighborhoods with higher socioeconomic status. More research is needed to see if this is the case.

In Kyrgyzstan, social capital in the form of informal financial aid is not a public good that is available to everyone. While the professionalization of social work is only emerging in the region, there are many opportunities to use the theory of social capital to develop social work interventions. First and foremost, social workers can work at a policy level. They can design policies that directly target the health needs of disadvantaged families through affordable health care and tax credits. Using instruments of the welfare state, social workers can improve policies, targeting assistance to the most disadvantaged families. Furthermore, policymakers can assess the availability of financial services in poor neighborhoods (Narayan-Parker, 1999), and link disadvantaged families to existing services. In addition, social workers can encourage lowincome families to start small businesses and strengthen existing businesses for expanding community economic developments (Midgley \& Livermore, 1998). Social workers can also address the mental health challenges associated with the double burden of social isolation and 
economic disadvantage, using this knowledge to organize counseling and group work to support families.

As social workers in the United States are taking on a growing role in addressing economic injustices (Lee, 2016), economic community development can be another line of social work intervention in post-Soviet countries. Social workers can educate low-income families in financial literacy and connect them to financial institutions and entrepreneurial opportunities (Lee, 2016). Social workers can also engage in supporting social businesses (defined as businesses for addressing social problems) within communities, which can provide venues for increased social cohesion at the neighborhood level. The development of community financial aid programs will reduce the burden placed on better-off families to provide neighborhood financial aid, while reducing the social and economic isolation of poor families and thereby increasing the overall social capital within communities. To conclude, social work scholars and practitioners engaging in studies and practice related to social capital and health should acknowledge the intersectionality between social and financial relations, and the resulting stratification between the poor and well-off families. 


\section{References}

Abekah-Nkrumah, G., Aseweh Abor, P., Abor, J., \& Adjasi, C. K. (2011). Improving maternal healthcare utilisation in sub-Saharan Africa through micro-finance. International Journal of Health Care Quality Assurance, 24, 601-610.

Afifi, R. A., Nakkash, R. T., \& Khawaja, M. (2010). Social capital, women's autonomy and smoking among married women in low-income urban neighborhoods of Beirut, Lebanon. Women's Health Issues, 20, 156-167.

Agampodi, T. C., Agampodi, S. B., Glozier, N., \& Siribaddana, S. (2015). Measurement of social capital in relation to health in low and middle income countries (LMIC): A systematic review. Social Science \& Medicine, 128, 95-104.

Borbieva, N.O.N. (2012). Troubled relations: Mobility and exchange in post-Soviet Kyrgyzstan. Ethnology: An International Journal of Cultural and Social Anthropology, 49(3), 167184.

Botoeva, A., \& Spector, R. A. (2013). Sewing to satisfaction: Craft-based entrepreneurs in contemporary Kyrgyzstan. Central Asian Survey, 32, 487-500.

Botoeva, G. (2015). The monetization of social celebrations in rural Kyrgyzstan: On the uses of hashish money. Central Asian Survey, 34, 531-548.

Brück, T., Esenaliev, D., Kroeger, A., Kudebayeva, A., Mirkasimov, B., \& Steiner, S. (2014). Household survey data for research on well-being and behavior in Central Asia. Journal of Comparative Economics, 42, 819-835. doi:10.1016/j.jce.2013.02.003

Cox, D., Eser, Z., \& Jimenez, E. (1997). Family safety nets during economic transition. In J. Klugman (Ed.), Poverty in Russia: Public policy and private responses (pp. 211-248). 
Retrieved from

http://documents.worldbank.org/curated/en/552951468759008099/pdf/multi-page.pdf

d'Hombres, B., Rocco, L., Suhrcke, M., \& McKee, M. (2010). Does social capital determine health? Evidence from eight transition countries. Health Economics, 19(1), 56-74.

Gilbert, K. L., Quinn, S. C., Goodman, R. M., Butler, J., \& Wallace, J. (2013). A meta-analysis of social capital and health: A case for needed research. Journal of Health Psychology, $18,1385-1399$.

Goryakin, Y., Suhrcke, M., Rocco, L., Roberts, B., \& McKee, M. (2014). Social capital and selfreported general and mental health in nine Former Soviet Union countries. Health Economics, Policy and Law, 9(1), 1-24.

Healy, K., \& Hampshire, A. (2002). Social capital: A useful concept for social work? Australian Social Work, 55, 227-238.

Howell, J. (1996). Coping with transition: Insights from Kyrgyzstan. Third World Quarterly, $17(1), 53-68$.

Hurtado, D., Kawachi, I., \& Sudarsky, J. (2011). Social capital and self-rated health in Colombia: The good, the bad and the ugly. Social Science \& Medicine, 72, 584-590.

Kawachi, I., Kennedy, B. P., Lochner, K., \& Prothrow-Stith, D. (1997). Social capital, income inequality, and mortality. American Journal of Public Health, 87, 1491-1498.

Kim, D., Subramanian, S. V., \& Kawachi, I. (2006). Bonding versus bridging social capital and their associations with self-rated health: A multilevel analysis of 40 US communities. Journal of Epidemiology and Community Health, 60(2), 116-122.

Kuehnast, K., \& Dudwick, N. (2002). Better a hundred friends than a hundred rubles? Social networks in transition - the Kyrgyz Republic. Retrieved from https://goo.gl/Vt75Ti 
Kuehnast, K., \& Dudwick, N. (2002). Better a hundred friends than a hundred rubles? Social networks in transition - the Kyrgyz Republic. In World Bank Economists' Forum (vol. 2, pp. 51-88).

Lee, W. (2016). Social work-business sector collaboration in pursuit of economic justice. Social Work, 61, 209-216.

Madhani, F. I., Tompkins, C., Jack, S. M., \& Fisher, A. (2015). Participation in micro-finance programmes and women's mental health in South Asia: A modified systematic review. Journal of Development Studies, 51, 1255-1270.

Midgley, J., \& Livermore, M. (1998). Social capital and local economic development: Implications for community social work practice. Journal of Community Practice, 5(12), 29-40.

Mohnen, S. M., Groenewegen, P. P., Völker, B., \& Flap, H. (2011). Neighborhood social capital and individual health. Social Science \& Medicine, 72, 660-667.

Narayan-Parker, D. (1999). Bonds and bridges: Social capital and poverty. Retrieved from https://goo.gl/fKvQgX.

Oka, N. (2015). Informal payments and connections in post-Soviet Kazakhstan. Central Asian Survey, 34, 330-340.

Podsakoff, P. M., MacKenzie, S. B., Lee, J. Y., \& Podsakoff, N. P. (2003). Common method biases in behavioral research: A critical review of the literature and recommended remedies. Journal of Applied Psychology, 88(5), 879-903.

Poortinga, W. (2006). Social relations or social capital? Individual and community health effects of bonding social capital. Social Science \& Medicine, 63(1), 255-270. 
Provis, R. (2015). Shifting social dynamics and economic inequality in the post-Soviet space: Networking and participation in toi among the novyi Kyrgyz. Economic Anthropology, 2, $371-384$.

Putnam, R. D. (2004). 'Health by association': Some comments [Commentary]. International Journal of Epidemiology, 33, 667-671.

Putnam, R., Leonardi, R., \& Nanetti, R. (1993). Making democracy work. Princeton. NJ: Princeton University Press.

Radnitz, S. (2005). Networks, localism and mobilization in Aksy, Kyrgyzstan. Central Asian Survey, 24, 405-424.

Singh-Manoux, A., Martikainen, P., Ferrie, J., Zins, M., Marmot, M., \& Goldberg, M. (2006). What does self-rated health measure? Results from the British Whitehall II and French Gazel cohort studies. Journal of Epidemiology and Community Health, 60, 364-372.

StataCorp. (2015). Stata Statistical Software: Release 14 [Computer software]. College Station, TX: Author.

Van Bastelaer, T. (2002). Understanding and measuring social capital: A multi-disciplinary tool for practitioners. In C. Grootaert \& T. Van Bastelaer (Eds.), Does social capital facilitate the poor's access to credit? (pp. 237-264). Washington, DC: International Bank for Reconstruction and Development.

Jildyz Urbaeva, PhD, is assistant professor and Theodore Jackson, MSW, and Daejun Park, MSW, are graduate research assistants, School of Social Welfare, University at Albany, State University of New York. Address correspondence to Jildyz Urbaeva, School of Social Welfare, 
SUNY University at Albany, 1400 Washington Avenue, Richardson 280, Albany, NY 12222; email: zurbaeva@albany.edu.

Original manuscript received June 14, 2017

Final revision received December 28, 2017

Editorial decision January 22, 2018

Accepted January 23, 2018 
Table 1: Descriptive Statistics

\begin{tabular}{lccrr}
\hline Categorical Variable & \% & SD & Min & Max \\
\hline Chronic disease & 25.90 & 0.44 & 0 & 100 \\
Female & 53.22 & 0.50 & 0 & 100 \\
Married or in union & 69.17 & 0.46 & 0 & 100 \\
Ethnic minority & 33.01 & 0.47 & 0 & 100 \\
Low level of income satisfaction & 14.56 & 0.35 & 0 & 100 \\
Mid level of income satisfaction & 35.85 & 0.48 & 0 & 100 \\
High level of income satisfaction & 49.60 & 0.50 & 0 & 100 \\
Informal cash loan & 35.45 & 0.48 & 0 & 100 \\
Informal loan for house repair & 83.71 & 0.37 & 0 & 100 \\
Rural residence & 65.23 & 0.48 & 0 & 100 \\
\hline Continuous Variable & $\boldsymbol{M}$ & $\boldsymbol{S D}$ & $\mathbf{M i n}$ & $\mathbf{M a x}$ \\
\hline Health satisfaction & 6.84 & 2.17 & 0 & 10 \\
Body mass index & 24.16 & 3.50 & 11.67 & 55.10 \\
Age (years) & 40.57 & 16.46 & 18 & 95 \\
\% of people who give financial aid in & 20.70 & 19.89 & 0 & 100 \\
$\quad$ the neighborhood & & & & \\
\% of people who receive financial aid & 20.00 & 21.70 & 0 & 100 \\
$\quad$ in the neighborhood & & & & \\
\hline
\end{tabular}


Table 2: Differences in Characteristics by Access to Informal Financial Aid

\begin{tabular}{|c|c|c|c|c|c|c|c|c|}
\hline Characteristic & $\begin{array}{c}\text { Access to } \\
\text { Small Loans }\end{array}$ & $\begin{array}{l}\text { No Access to } \\
\text { Small Loans }\end{array}$ & $\chi^{2}$ & $p$ & $\begin{array}{c}\text { Access to } \\
\text { House } \\
\text { Repair Loans } \\
(\%)\end{array}$ & $\begin{array}{c}\text { No Access } \\
\text { to House } \\
\text { Repair } \\
\text { Loans } \\
(\%)\end{array}$ & $\chi^{2}$ & $p$ \\
\hline Chronic disease & 25.80 & 25.98 & 0.03 & .864 & 25.86 & 26.19 & 0.06 & .806 \\
\hline Female & 48.00 & 56.07 & 44.71 & .000 & 53.26 & 52.96 & 0.04 & .850 \\
\hline Married or in union & 74.49 & 66.22 & 54.80 & .000 & 69.93 & 65.13 & 10.99 & .001 \\
\hline Minority & 33.98 & 32.52 & 1.64 & .200 & 33.22 & 32.07 & 0.61 & .436 \\
\hline Household income & & & 144.95 & .000 & & & 86.76 & .000 \\
\hline Low income & 9.16 & 17.51 & & & 13.10 & 21.96 & & \\
\hline Mid-level income & 32.97 & 37.48 & & & 35.34 & 38.64 & & \\
\hline High income & 57.87 & 45.02 & & & 51.57 & 39.40 & & \\
\hline Characteristic & $M(S D)$ & $M(S D)$ & $t$ Test & $p$ & $M(S D)$ & $M(S D)$ & $t$ Test & $p$ \\
\hline Health & $7.18(0.04)$ & $6.65(0.03)$ & -10.11 & .000 & $6.92(0.03)$ & $6.41(0.07)$ & -7.61 & .000 \\
\hline $\begin{array}{l}\% \text { of people who give } \\
\text { financial aid }\end{array}$ & $25.63(0.44)$ & $17.99(0.26)$ & -16.16 & .000 & $21.45(0.26)$ & $16.80(0.50)$ & -7.49 & .000 \\
\hline $\begin{array}{l}\% \text { of people who receive } \\
\text { financial aid }\end{array}$ & $24.43(0.47)$ & $17.57(0.29)$ & -13.22 & .000 & $20.50(0.28)$ & $17.44(0.58)$ & -4.50 & .000 \\
\hline Age & $41.80(0.30)$ & $39.89(0.24)$ & -4.81 & .000 & $40.63(0.21)$ & $40.27(0.49)$ & -0.70 & .242 \\
\hline Body mass index & $24.58(0.07)$ & $23.98(0.05)$ & -7.15 & .000 & $24.20(0.04)$ & $24.13(0.10)$ & -0.60 & .274 \\
\hline
\end{tabular}


Table 3: Multilevel Linear Regression of Individual and Neighborhood-Level Social Capital on Perceived Health Satisfaction

\begin{tabular}{|c|c|c|c|c|c|c|}
\hline \multirow[t]{2}{*}{ Variables } & \multicolumn{2}{|c|}{ Model 1} & \multicolumn{2}{|c|}{ Model 2} & \multicolumn{2}{|c|}{ Model 3} \\
\hline & $B$ (SE) & $p$ & $B$ (SE) & $p$ & $B$ (SE) & $p$ \\
\hline \multicolumn{7}{|l|}{ Individual-level social capital } \\
\hline Access to informal cash loan & $0.25(0.05)$ & $<.001$ & $0.26(0.05)$ & $<.001$ & $0.37(0.07)$ & $<.001$ \\
\hline Access to informal house repair loan & $0.29(0.06)$ & $<.001$ & $0.29(0.06)$ & $<.001$ & $0.27(0.08)$ & .001 \\
\hline \multicolumn{7}{|l|}{ Neighborhood-level social capital } \\
\hline$\%$ of people who give financial aid & & & $0.04(0.00)$ & .035 & $0.01(0.00)$ & .008 \\
\hline$\%$ of people who receive financial aid & & & $-0.01(0.00)$ & $<.001$ & $-0.01(0.00)$ & $<.001$ \\
\hline \multicolumn{7}{|l|}{ Interactions } \\
\hline Cash loan $\times \%$ giving financial aid & & & & & $-0.02(0.00)$ & $<.001$ \\
\hline Cash loan $\times \%$ receiving financial aid & & & & & $0.01(0.00)$ & .010 \\
\hline House repair loan by $\times$ giving & & & & & $-0.00(0.01)$ & .572 \\
\hline financial aid & & & & & & \\
\hline $\begin{array}{l}\text { House repair loan by } \times \text { receiving } \\
\text { financial aid }\end{array}$ & & & & & $0.00(0.00)$ & .341 \\
\hline \multicolumn{7}{|l|}{ Random effects } \\
\hline Intercept & $7.24(0.20)$ & & $7.34(0.20)$ & & $7.31(0.21)$ & \\
\hline Residual & $2.94(0.05)$ & & $2.94(0.05)$ & & $2.94(0.05)$ & \\
\hline & 275.49 & $<.001$ & 263.63 & $<.001$ & 268.68 & $<.001$ \\
\hline Intra-class correlation & 0.04 & & 0.04 & & 0.04 & \\
\hline
\end{tabular}

Note: All models were adjusted for income, chronic disease, body mass index, age, gender, marital status, and ethnicity. 
Figure 1. Interaction between Health Satisfaction and Given Financial Aid in Neighborhood

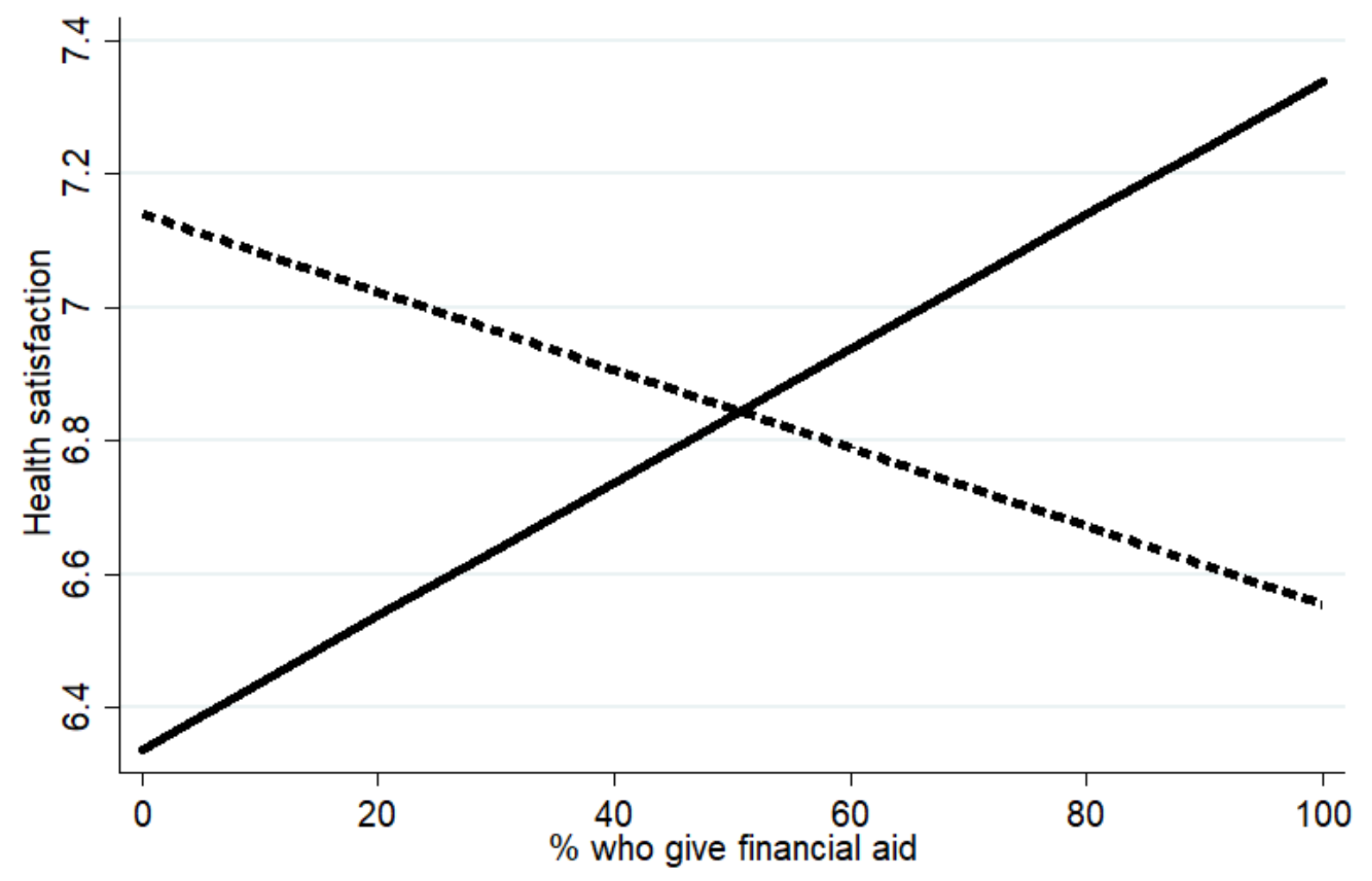

No access to cash loans

-10-1. Access to cash loans 
Figure 2. Interaction between Health Satisfaction and Received Financial Aid in Neighborhood

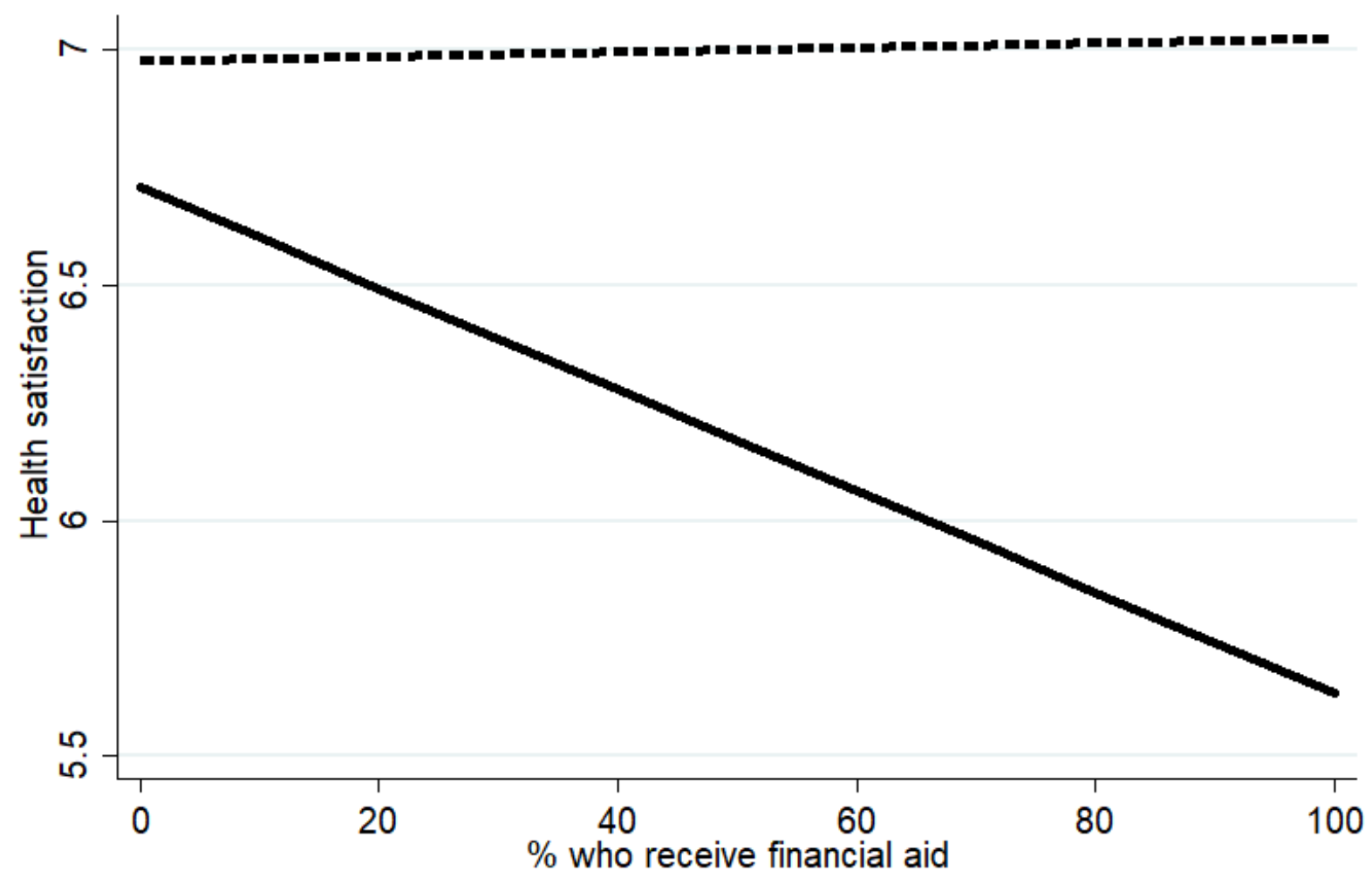

No access to cash loans 